\title{
ASSESSMENT OF SAFETY AND ECONOMY OF NAVIGATION IN ICE ON THE NORTHERN SEA ROUTE
}

This article discusses safety and economic issues of sea transport during transit voyages of a vessel across the North Sea Route (NSR) in the Arctic Ocean. The main obstacles to shipping and threat to vessels are the regions of ice occurrence and, in particular, clusters of ice with high and very high concentration, thickness and hummocking occurring each year in the same places, which are called ice massifs. Speed of vessels has the greatest impact on the economy of transit voyage. The safe speed of vessels, as a means of transport that ensures trouble-free navigation of the vessels depends on ice conditions. Until now, the concept of safe speed has not been precisely defined. Also, the impact of speed of the vessel in certain ice conditions on overcoming the ice and the risk of damage to vessel has not been precisely defined. Issues of direct and potential costs of vessel's safety, damages and consequences of damages in ice were also not fully considered. The author analyzed the above relationships on the example of the first commercial vessel transit voyage through the NSR and obtained generalized results that can be applied to the initial, general and tactical route planning till 10 days - 6 months ahead and transit schedule of a vessel between Europe and the Far East ports via the Northern Sea Route. The presented method should increase safety and economy of sea transportation in areas covered with ice.

\section{INTRODUCTION}

There was a significant reduction of ice extent in the Arctic in last twenty years. That's why came favorable conditions for shipping by vessels of low ice classes, especially along the Russian Arctic coast. Ice cover found in this area pose a particular danger to vessels, regardless of the existing ice-strengthened hull and a power of propulsion system. Persons planning voyage of a vessel in icecovered areas need a tools to make decisions justified by a cost analysis. The basic measures of voyage costs are fuel used and chartering time of the vessel. In areas covered with ice, additional unexpected costs may occur in the form of longer voyage time. The reason may be lower speed due to higher resistance of hull in ice, the need to extend length of route to avoid larger areas covered by heavy ice, beset and nip of a vessel in close or very close ice and the need to use paid services of icebreakers. Another element of difficult to predict costs is the possibility of damage to propulsion system, rudder, hull or even sinking, i.e. the loss of a vessel. Emer-

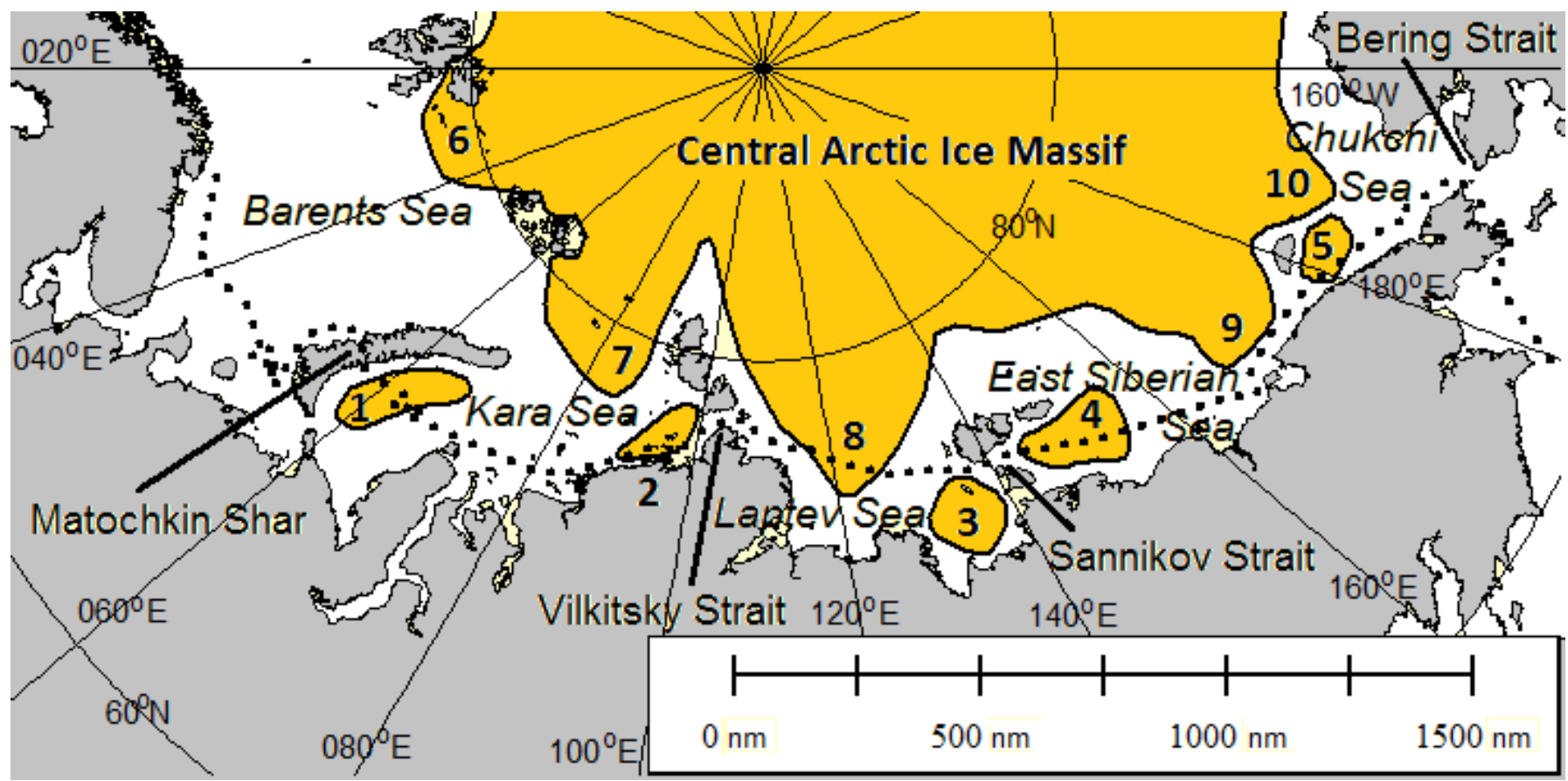

Fig. 1. General locations of ice massifs in the Russian Arctic during summer period: 1 - Novaya Zemlya, 2 - Severnaya Zemlya, 3 - Yana, 4 - New Siberian, 5 - Wrangel, 6 - Spitsbergen, 7 - North Kara, 8 - Taymyr, 9 - Ayon, 10 - North Chukchi; - . - the analyzed route of the vessel's first commercial transit voyage completed by reaching the destination in one summer navigation season. Made by author based on [1, 2, 9, 14]; Land map made with Natural Earth - Free vector and raster map data @ naturalearthdata.com 
gency situations may cause costs of rescue, towing and current repairs as well as costs of shipyard repairs and dry docking.

\section{PURPOSE AND SCOPE OF THE WORK}

The author of the work decided to analyze relatively well documented case of the first commercial transit voyage of the ship through the Northern Sea Route (NSR) leading along the Russian Arctic coast, that carried out in one navigation season in 1940. The purpose of the intended analysis is to find relationships between statistical data of ice massifs area, area covered by ice on particular regions of the NSR and ice concentration "on-scene" with capability of cargo ship to overcome the ice and the speed of the ship when sailing alone and in convoy following an icebreaker decided to use statistical data of relative area of ice massifs [1, 2], relative area of particular parts of seas along the NSR and details of successful transit voyage of the German ship in 1940. For this purpose, collected all possible information about the ship and her transit voyage essential for the reconstruction of the navigation data and ice conditions present at the time of voyage $[1,2,5,8]$. The term "ice massifs" $[4,9]$ should be understood as areas with surface over 1 thousand square kilometers made up of close and very close pack ice with a high thickness and considerable hummocking usually accumulating in specific parts of the Arctic seas (Fig. 1). As a result of the research, it is planned to find relationships allowing for making justified decisions in scope of planning schedule and costs of vessel's voyage in ice-covered regions. These include the commonly known costs and potential costs resulting from unusual and emergency situations related to shipping in ice. This should improve the safety of maritime transport and economically efficient vessel voyage planning.

\section{TECHNICAL DATA OF THE ANALYZED VESSEL}

The ship Komet was built as a merchant ship. Her technical parameters were as follows: length 115.5 meters, draft 6.5 meters, wide 15.3 meters, navigation range (autonomy) 35,100 nautical miles, 3,287 gross register tons (GRT), deadweight 6,892 metric tons, powered by two 6-cylinder two-stroke MAN diesel engines, producing $3,900 \mathrm{HP}(2,908 \mathrm{~kW})$, propeller single shaft, range of 51,000 nautical miles at 9 knots $[5,8,16]$. Before beginning of voyage through the Northern Sea Route, the ship was equipped with a specially strengthened hull and bow, and propeller blades suitable to navigate in ice. Before reconstruction her full sea speed was 16 knots, after adapting for ice navigation 14.7 knots. The deadweight and total shaft power places this ship in ice class ULULA (RMRS), L1A (PRS), IA Super (Finnish-Swedish ice class) or polar class PC6 (IACS Polar Rules) according to 2016 regulations [15]. Need to mention, the ship was built to sail outside ice covered regions. Later was adapted for navigation in difficult ice conditions without the assistance of icebreakers and to operate in open sea conditions corresponding to a level ice thickness not exceeding 1.0 meter, with minimum speed of 5 knots in the brash ice channels of ice thickness up to 1.0 meter and a 0.1 meter consolidated layer of ice [6]. The ability of the vessel to overcome an ice is expressed in aspect ratio of displacement in metric tons to output power of propulsion engine in horsepower units $[3,4,7,13]$. This factor for ship Komet was equal 1.77. Safety requirement was value below 2.0. Then ship Komet was able to proceed alone in ice conditions described for ice class UL-ULA (IA Super).

\section{VOYAGE SCHEDULE OF THE VESSEL AND TIME- GEOGRAPHICAL DATA SPATIAL DISTRIBUTION}

The ship sailed on a voyage from Gdynia (Gotenhafen) on 3 July 1940. Then sailed along the coast of Norway to Teriberka [13, 17]. Between July 15 and August 13 of 1940, ship remained in ice covered waters of the Barents Sea, mainly in drift, occasionally at anchor [5, 8]. During the second week of August the ship received reports of favorable ice conditions on her way through the pack-ice and proceeded eastwards with maximum speed, leaving her anchorage on August 13, and heading into the entrance to the Matochkin Shar Strait. The following day, August 14, the ship arrived at the meeting point and took two Russian pilots on. Passed over 160 miles into the Kara Sea, but with no ice-breaker Lenin yet available for assistance, the ship was forced to return to the Matochkin Shar Strait on August 15, and remain at anchor there till August 19. On August 19, received orders to proceed along a very precise course. The ship forced her way through the melting ice-field, and reached open water on August 22.

On August 23, ship joined the ice-breaker Lenin and followed her through the Vilkitsky Strait. By midnight on August 26 the ship with icebreaker had passed Cape Chelyuskin. The waters were free of ice and the icebreaker Lenin assistance was in fact not necessary. Later on August 26 the ship Komet joined the icebreaker Stalin. On August 27, the ship resumed her voyage. The Lenin turned back to the Kara Sea.

The Stalin led the Komet through the thick pack-ice and dense fog in Taymyr massif in Western part of Laptev Sea into open waters on August 28. Then the icebreaker Stalin left the ship. The Komet should contact the ice-breaker Lazar Kaganovitch. Because the floating ice was not expected later on her way on August 28, the ship passed Sannikov Strait without waiting for icebreaker Malygin being on duty. Experiencing little difficulty with ice over the next two days the ship Komet joined icebreaker Lazar Kaganovitch on August 30. Was instructed to follow closely in her wake. Heavy ice was expected ahead. During a difficult 48-hour period August in Ayon Ice Massif in Eastern part of East Siberian Sea the ship Komet twice became beset in ice and had to be freed by icebreaker. She also sustained damage to her rudder. On September 1 the ship and icebreaker dropped anchors. The voyage through the ice was not completed. Due to political reasons rest of the route through heavy ice at a distance of $400 \mathrm{~nm}$ from the ice-free Bering Strait only the ship Komet passed alone.

On the morning of September 5 vessel reached the Bering Strait. Commander of the Komet acknowledged that the ship could not have pass her route successfully without assistance of icebreakers. The route of the ship on the NSR is shown on Figure 1.

\section{RESULTS}

Complete set of analyzed data was collected in Table 1. Various correlations were found that allow draw several conclusions. The ice massif $0 \%$ relative area or up to $12 \%$ coverage of region by ice or "ice-free conditions (CT=0-18\%) allow independent voyage of a vessel at nearly maximal sea speed. The ice massif $0-4 \%$ relative area or $19-45 \%$ coverage of region by ice or ice concentration 10 $60 \%$ allow independent voyage of a vessel with difficulties at speed up to 6.9 knots. The ice massif $58 \%$ relative area or $81 \%$ coverage of region by ice or ice concentration variable from $10 \%$ till $80 \%$ require assistance of icebreaker and proceed vessel in convoy. No damages to vessel should be expected. The ice massif $77 \%$ relative area or $91 \%$ coverage of region by ice and total ice concentration CT varying from $90 \%$ till $100 \%$ require assistance of icebreaker and proceed vessel closely icebreaker in convoy. Vessel may be beset 
in ice, suffer damage to its hull, rudder or propeller. Maximal efforts must be given during independent voyage without icebreaker to proceed forward and avoid beset in ice.

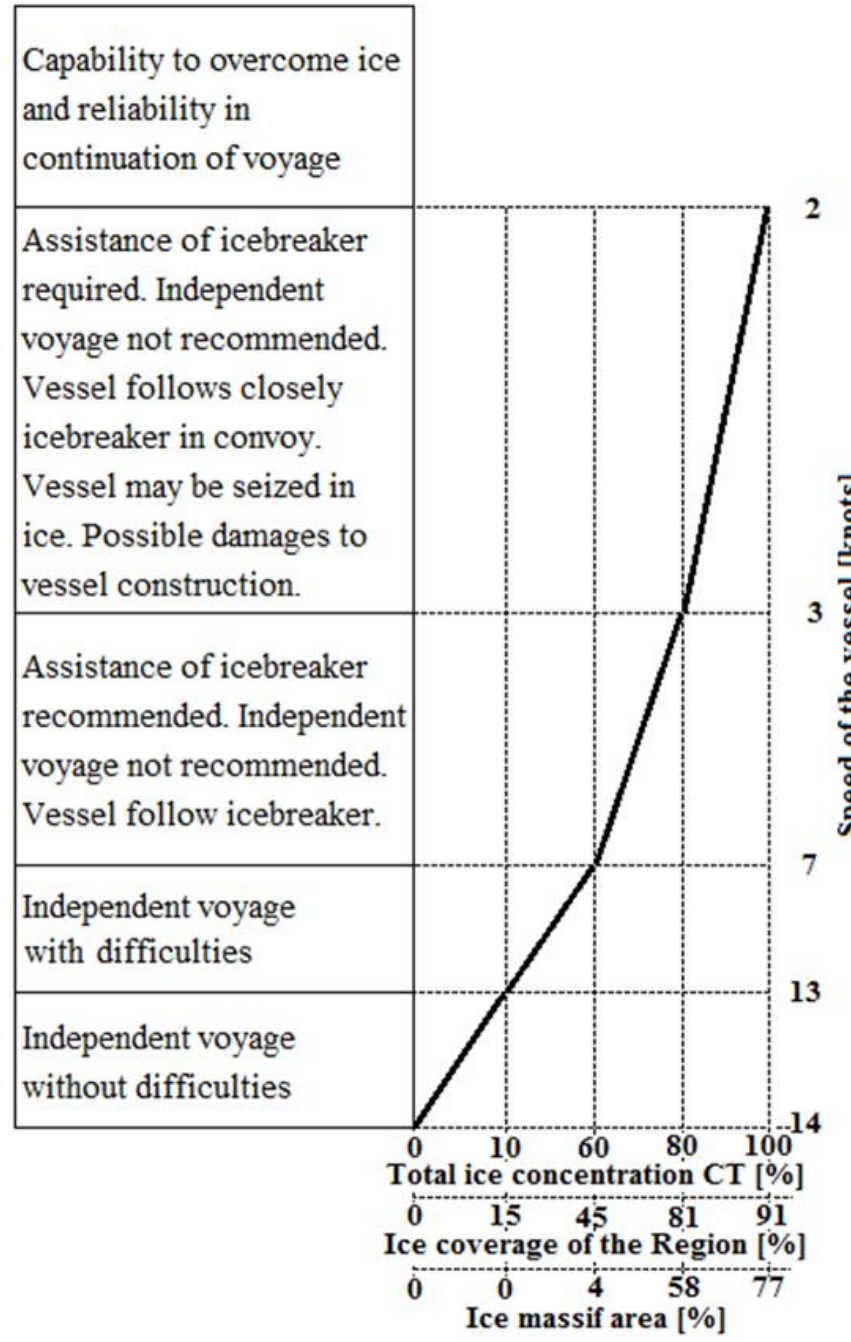

Fig. 2. Generalized decision-making support diagram of safety of vessel in ice for initial, general and tactical voyage planning. Made by the Author.

Above summarized results were presented on synthetic diagram (Figure 2). There are presented maximal safe speed and capability to overcome ice conditions and reliability in continuation voyage in relation to percentage of ice massifs, ice covered regions and total concentration of ice floe related to a vessel of ice class ULULA (1A Super). This diagram is not recommendation for vessels commanders in relation to safe technical speed. It should be assumed as advisory application to support decision-making process of initial (3-6 months ahead), general (1-3 months ahead) and tactical (10-30 days ahead) voyage planning [10] based on statistical data.

Due to a little incomplete description of voyage details $[5,8]$ the calculated speed of vessel (Table 1) may be not exact. However was possible to describe relations in between speed of the vessel in ice with assistance of icebreaker and during independent voyage (Figure 3). Benefits coming from use of icebreaker at low concentration of ice is low. There is only 1.40 times higher speed when uses assistance of icebreaker at $40 \%$ concentration of ice. The increase of speed is much higher at ice concentration above $50 \%$. This increase is equal $1.64,2.00$ and 2.20 times at $60 \%, 80 \%$ and $100 \%$ of total concentration respectively. It means the assistance of ice- breaker looks giving real speed-up benefits at $60 \%$ of ice concentration or higher. Additionally increases safety and reliability to complete successfully voyage in ice.

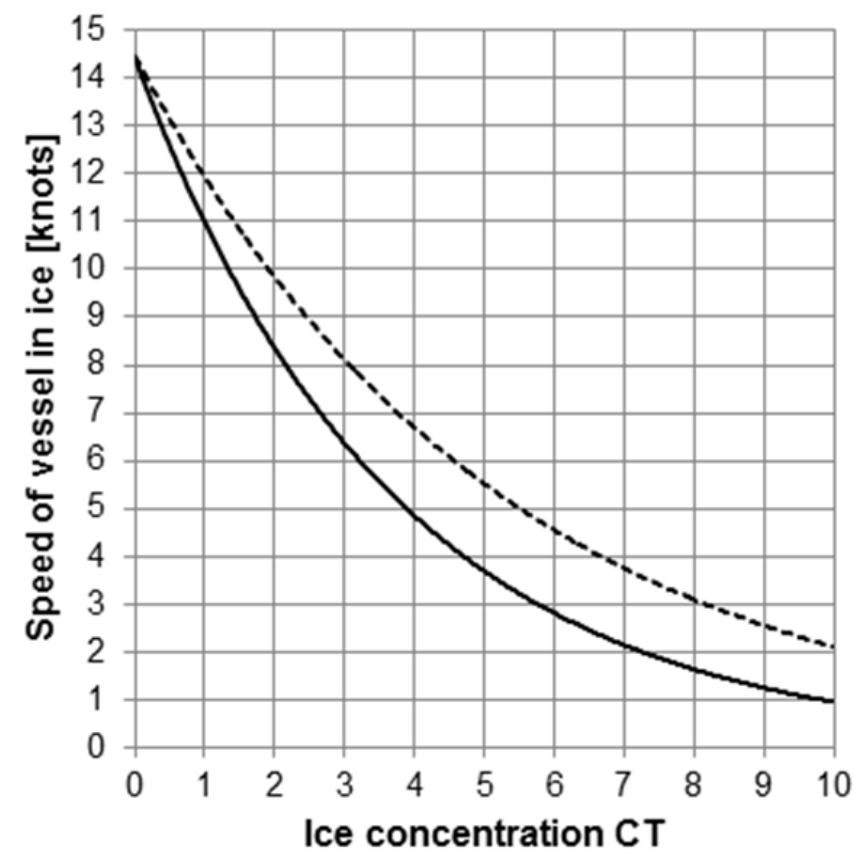

Fig. 3. Generalized decision-making support diagram of speed of vessel in ice for initial, general and tactical voyage planning. Made by the Author.

\section{CONCLUSIONS}

Ice conditions in the Arctic can be equivalently described using one of the three features of the ice cover. There are relative ice massif area of the particular region, ice coverage of the particular region and total concentration of ice cover. The first two are related to statistical data. Third one, i.e. total ice concentration is related to ice conditions being encountered by the vessel in the area of current navigation. The relationships presented in concise form of diagrams allow easy use of statistical prognostic data available on the web site of the NSR Administration [11] for initial and general vessel's voyage schedule and costs planning.

Relationship in between total ice concentration and speed of the vessel in independent voyage or with assistance of icebreaker allows to calculate gains of speed and same time voyage time savings. Assistance of icebreaker reduces fuel consumption of a vessel. Increased speed of a vessel assisted by icebreaker reduces time of the voyage, it means reduces costs of chartering. Reduced costs of saved fuel and chartering time require comparison with costs of icebreaker services imposed by the NSR Administration [12].

By this way the decision-making person that is planning voyage of the vessel and / or master of the vessel may take decisions related to get icebreaker services or not. On one side is relatively high cost of icebreaker assistance. On other side are saved costs of fuel, saved time of chartering vessel, reduction of uncertain time of a vessel voyage (possible beset and nip in ice) and risks of damage to a vessel (costs of possible emergency towing, repairs, dry docking and time lost). The use of presented in the work method offers making decision justified by the safety and cost analysis. Can be used in decision-making system in the office of a vessel Operator or Charterer, or on board vessel. Then should improve safety of maritime transport and economically efficient vessel voyage planning. 


\section{Bezpieczeństwo i ekologia}

\begin{tabular}{|c|c|c|c|c|c|}
\hline $\begin{array}{c}\text { Date in } \\
1940\end{array}$ & Region & Ice massif & $\begin{array}{l}\text { Ice massif } \\
\text { relative area } \\
{[\%]}\end{array}$ & $\begin{array}{l}\text { Regions relative } \\
\text { area covered by } \\
\text { ice [\%] }\end{array}$ & Remarks \\
\hline 14-20 Aug & $\begin{array}{l}\text { Kara Sea } \\
\text { SW part }\end{array}$ & $\begin{array}{l}\text { Novaya } \\
\text { Zemlya }\end{array}$ & 0 & 19 & $\begin{array}{l}\text { Unable to pass ice without icebreaker. Returned from its way. Awaiting better ice } \\
\text { conditions for } 4 \text { days. Than forced the way through melting ice field. Ice concentra- } \\
\text { tion CT=30-60\%. Average speed } 6.9 \text { knots }\end{array}$ \\
\hline 23-25 Aug & $\begin{array}{l}\text { Kara Sea } \\
\text { NE part }\end{array}$ & $\begin{array}{l}\text { Severnaya } \\
\text { Zemlya }\end{array}$ & 0 & 12 & $\begin{array}{l}\text { Passed with assistance of icebreaker Lenin. Ice-free conditions. Average speed } \\
12.9 \text { knots. }\end{array}$ \\
\hline 26-27 Aug & $\begin{array}{l}\text { Laptev Sea } \\
\text { Western part }\end{array}$ & Taymyr & 58 & 81 & $\begin{array}{l}\text { Passed with assistance of icebreaker Stalin. Ice concentration CT=10-80\%. } \\
\text { Average speed } 9 \text { knots. }\end{array}$ \\
\hline 27 Aug. & $\begin{array}{l}\text { Laptev Sea } \\
\text { Eastern part }\end{array}$ & Yana & 0 & 83 & $\begin{array}{l}\text { Passed thick ice pace without assistance of icebreaker. Ice concentration CT=10- } \\
80 \% \text {. Average speed } 7.6 \text { knots. }\end{array}$ \\
\hline 28 Aug & $\begin{array}{l}\text { Sannikov } \\
\text { Strait }\end{array}$ & $\mathrm{n} / \mathrm{a}$ & $\mathrm{n} / \mathrm{a}$ & 0 & $\begin{array}{l}\text { Passed without assistance of icebreaker Malygin. Ice-free conditions. Average } \\
\text { speed } 14 \text { knots. }\end{array}$ \\
\hline 28-30 Aug & $\begin{array}{l}\text { East Siberian } \\
\text { Sea } \\
\text { Western part }\end{array}$ & $\begin{array}{l}\text { New } \\
\text { Siberian }\end{array}$ & 4 & 45 & $\begin{array}{l}\text { Voyage without icebreaker with a little difficulty in ice. Ice concentration CT=20- } \\
30 \% \text {, later } 10-50 \% \text {. Average speed } 5.7 \text { knots. }\end{array}$ \\
\hline $\begin{array}{l}30 \text { Aug - } \\
01 \text { Sep }\end{array}$ & $\begin{array}{l}\text { East Siberian } \\
\text { Sea } \\
\text { Eastern part }\end{array}$ & Ayon & 77 & 91 & $\begin{array}{l}\text { Difficult voyage following closely icebreaker Lazar Kaganovitch. Two times became } \\
\text { beset in ice and was released by icebreaker. Sustained damage to her rudder. Ice } \\
\text { concentration CT=90\%. Average speed } 2.2 \text { knots. }\end{array}$ \\
\hline 03 Sep & $\begin{array}{l}\text { East Siberian } \\
\qquad \text { Sea } \\
\text { Eastern part }\end{array}$ & Ayon & 73 & 91 & $\begin{array}{l}\text { Ice conditions required help of icebreaker. Ice concentration CT=90\%. Independ- } \\
\text { ent successful voyage in ice with average speed about } 1 \text { knot. }\end{array}$ \\
\hline 03-05 Sep & $\begin{array}{l}\text { Chukchi Sea } \\
\text { SW part }\end{array}$ & Wrangel & 0 & 6 & Ice-free conditions. Average speed 14.3 knots. \\
\hline
\end{tabular}

\section{REFERENCES}

1. AARI, Sea-ice extent of the Arctic and its regions. [in Russian] (Ледовитость арктических морей и их районов). ESIMO, 2014, http://www.aari.ru/ [Date accessed 03.03.2014].

2. AARI, Surface of ice massifs. [in Russian] (Площади ледяных массивов). ESIMO, 2015, http://www.aari.ru/ [Date accessed 08.07.2015].

3. Anosov A.V., Didyk A.D., Ship management and its technical operation [in Russian] (Управление судном и его техничесая експлоатация). Moscov, Transport, 1969.

4. Arikaynen A.l., Navigation in the Arctic ice. [in Russian] (Судоходство во льдах Арктики). Transport, Moscov, 1990.

5. Brennecke J., The German auxiliary cruiser in World War II, [in German] (Die deutschen Hilfkreuzer in Zweiten Weltkrieg). Koehlers Verlagsgesellschaft MBH, Hamburg, 2001.

6. DNV, Rules for Classification of Det Norske Veritas AS, Ships, Part 5 Chapter 1, Newbuildings, Special service and type - Additional Class, Ships for Navigation in Ice, July 2011.

7. Duda D., Jankowski E., Kazanecki E., Navigation in ice conditions. [in Polish] (Żegluga w warunkach lodowych). Wyższa Szkoła Morska, Gdynia, 1970.

8. Eyssen R., HSK Komet. Looting on all the seas. [in German] (HSK Komet. Kaperfahrt auf allen meeren). Koehler, Hamburg, 2002.

9. GUNiO, The guide to navigating through the northern sea route. GUNiO, no 4151B, 1996.

10. Khvochtchinski N.I., Batskikh Yu.M., The northern sea route as an element of the ICZM system in the Arctic: problems and perspectives. Elsevier, Ocean \& Coastal Management 41, 1998.

11. NSRA/1, Long-term forecasts, http://nsra.ru/ru/navigatsionnaya_i_gidrometinformatsiya/dolgosrochnie_prognozi.html [Date assessed 10.02.2018].
12. NSRA/2, Calculation of the cost of icebreakers services in the NSR waters, http://nsra.ru/ru/ledokolnaya_i_ledovaya_lotsmanskaya_provodka/raschet_stoimosti_ledokolnoy_provodki_v_akv atorii_smp.html, [Date accessed 10.02.2018].

13. Pastusiak T., The Northern Sea Route as a shipping lane. Expectations and Reality. ISBN 978-3-319-41832-2, ISBN eBook 978-3-319-41834-6, Springer International Publishing AG, Switzerland, 2016.

14. Ragner C.L., Northern Sea Route Cargo Flows and Infrastructure-Present State and Future Potential. The Fridtjof Nansen Institute, Report 13, 2000.

15. RMRS, Rules for the classification and construction of seagoing ships. Part 1, Classification, Electronic version of printed document approved on 30.09.15, Russian Maritime Register of Shipping, Saint-Petersburg, Edition 2016, 2016.

16. Silenthunter, Raidery Kriegsmarine, http://silenthunter.pl/raidery-kriegsmarine-t168.html [Date accessed 28.02. 2014].

17. Wikipedia, http://en.wikipedia.org/wiki/German_auxiliary_cruiser_Komet [Date accessed 28.02.2014].

\section{LIST OF ACRONYMS}

AARI - Arctic and Antarctic Research Institute

CT - Total Concentration (of ice cover)

DNV - Det Norske Veritas

ESIMO - ЕСИМО, Единая Система Информации об обстановке в Мировом Океане (in Russian, no English name appointed)

GUNiO - ГУНиO, Главное Управление Навигации и Океанографии (English: Head Department of Navigation and Oceanography, or HDNO)

IACS - International Association of Classification Societies

NSR - Northern Sea Route

NSRA - Northern Sea Route Administration

PRS - Polish Register of Shipping

RMRS - Russian Maritime Register of Shipping 


\section{Ocena bezpieczeństwa i ekonomiki żeglugi w lodach na Pół- nocnej Drodze Morskiej}

$W$ artykule omówiono zagadnienia bezpieczeństwa i ekonomiczne transportu morskiego podczas podróży tranzytowych statku przez Pólnocna Drogę Morska (PDM) na Oceanie Arktycznym. Głównym utrudnieniem dla żeglugi i zagrożeniem dla statków sa na niej rejony wystepowania lodu a $w$ szczególności skupiska lodu o dużej i bardzo dużej zwartości, grubości $i$ zwałowaniu, występujace każdego roku $w$ tych samych miejscach, które sa nazywane masywami lodowymi. Największy wplyw na ekonomiczność podróży tranzytowych stanowi prędkość statku. Bezpieczna prędkość statku, jako środka transportu, która zapewni bezawaryjna jego nawigację zależy od warunków lodowych. Do chwili obecnej pojęcie prędkości bezpiecznej nie zostało precyzyjnie określone. Również wplyw prędkości statku w określonych warunkach żeglugi lodowej na utrudnienie żeglugi i zagrożenie uszkodzeniami statku nie zostaly precyzyjnie ustalone. Nie byty rozpatrywane również kwestie bezpośrednich i potencjalnych kosztów zagrożenia bezpieczeństwa statku $w$ lodach. Autor przeanalizowal powyższe zależności na przykładzie przypadku pierwszej komercyjnej podróży tranzytowej statku przez PDM i uzyskat uogólnione wyniki, które moga być zastosowane do wstepnego, generalnego i taktycznego planowania trasy i harmonogramu podróży tranzytowej statku pomiędzy Europa i portami Dalekiego Wschodu przez Pótnocna Droge Morska. Przedstawiona metoda powinna zwiększyć bezpieczeństwo i ekonomiczność transportu morskiego $w$ rejonach pokrytych lodem.

Author:

dr inż. kpt.ż.w. Tadeusz Pastusiak - Gdynia Maritime University, Gdynia, Department of Navigation, e-mail:tadeusz.pastusiak@wp.pl

JEL: R41 DOI: 10.24136/atest.2018.062

Data zgłoszenia: 2018.05.21 Data akceptacji: 2018.06.15 